DOI https://doi.org/10.36059/978-966-397-235-0-12

Левченко А. В.,

аспірантка кафедри конституційного, адміністративного та кримінального права Київського національного економічного університету імені Вадима Гетьмана, м. Київ

\title{
СТАНОВЛЕННЯ ТА РОЗВИТОК ПРАВА НА ТАЄМНИЦЮ ЛИСТУВАННЯ, ТЕЛЕФОННИХ РОЗМОВ, ТЕЛЕГРАФНОЇ ТА ІНШОЇ КОРЕСПОНДЕНЦІЇ ЯК ПРАВО ПЕРШОГО ПОКОЛІННЯ
}

Анотація. $у$ статті розглянуто питання становлення, розвитку та сучасного стану одного з прав першого покоління права на таємницю листування, телефонних розмов, телеграфної та іншої кореспонденції. Зазначається, що стрімкий розвиток інформаційних технологій та поява нових видів кореспонденції зумовлюють необхідність дослідження того, як сучасні умови життєдіяльності людини впливають на одне з найдавніших прав людини. Сформувавшись ще за часів існування античних держав у формі неписаного права як похідне від права на повагу і недоторканність приватного і сімейного життя, сьогодні це право дійсно реалізується в абсолютно нових умовах, зумовлених розвитком інформаційних технологій. Автором досліджено шлях становлення і розвитку права на таємницю кореспонденції. З'ясовано, що на сучасному етапі реалізації цього права виникає чимало проблем. На практиці виникають ситуації, коли задеклароване на конституційному рівні право на таємницю кореспонденції порушується з боку інших осіб або держави, тому автором запропоновано можливі шляхи вирішення зазначених проблем, які дадуть змогу створити ефективну систему забезпечення права на таємницю листування, телефонних розмов, телеграфної та іншої кореспонденції.

\section{Вступ}

Загальна декларація прав людини проголошує у статті 2: «Кожна людина повинна мати всі права і всі свободи, проголошені цією Декларацією, незалежно від раси, кольору 
шкіри, статі, мови, релігії, політичних або інших переконань, національного чи соціального походження, майнового, станового або іншого становища». Очевидно, що дотримання прав і свобод людини $\epsilon$ пріоритетним завданням кожної демократичної держави. Безумовно, у сучасному цивілізованому світі людина $\epsilon$ найвищою соціальною цінністю, а основним завданням держави стає закріплення в законах прав і свобод та забезпечення їх реалізації [1, с. 190].

Основні права і свободи людини забезпечують різні сфери іï життєдіяльності: особисту, соціальну, економічну, політичну, культурну. Відповідно до цього, їх класифікують за групами, до кожної з яких відносять певний перелік таких прав і свобод. Але варто зауважити, що права i свободи людини не лише відносяться до різних сфер іiї життєдіяльності, вони також розрізняються за часом свого виникнення, у хронологічному порядку [2, с. 48].

Так, унаслідок особливостей історичного розвитку прав людини різні категорії прав виникали не одночасно, а з'являлися послідовно. Спочатку сформувалося перше покоління покоління природних прав людини, потім друге покоління покоління гарантій у певних сферах життєдіяльності, зокрема у соціальній, економічній та культурних сферах. Під час розвитку і збагачення двох перших поколінь виникло третє - покоління колективних прав, до яких відносять права національних меншин, іноземних громадян, жінок, дітей, інвалідів [3, с. 58]. У XXI ст. науковці говорять про становлення четвертого покоління прав людини, яке виникає внаслідок наукових відкриттів у галузі мікробіології, медицини, генетики [4, с. 164], а також розбудови інформаційного суспільства, що нерозривно пов'язано із забезпеченням інформаційних прав людини [5, с. 55].

Уважається, що права першого покоління - це основа інституту прав людини, до яких відносять невідчужувані особисті і політичні права [2, с. 48], серед яких і гарантоване Конституцією України право на таємницю листування, телефонних розмов, телеграфної та іншої кореспонденції. Сьогодні інтенсивний та динамічний розвиток інформаційних та телекомунікаційних технологій, активне впровадження їх у життєдіяльність суспільства [5, с. 55] та поява і розвиток нових видів кореспонденції зумовлюють необхідність дослідження того, як це все впливає на забезпечення і дотримання права на 
таємницю листування, телефонних розмов, телеграфної та іншої кореспонденції як права першого покоління. Тож потрібно дослідити 3 теоретико-правових та історико-правових позицій процес становлення i розвитку права на таємницю кореспонденції, причин, які зумовили його виникнення, історичний шлях від моменту становлення до сьогодення, а також сучасний стан забезпечення і реалізації цього права. Таким чином, на прикладі досліджуваного права можливо відстежити, як зміна поколінь людей та умов їхньої життєдіяльності впливає на розвиток прав людини першого покоління. Це зумовлює актуальність дослідження та його мету - простежити особливості розвитку та проаналізувати сучасний стан забезпечення і реалізації цього права та спрогнозувати можливі шляхи вирішення проблемних питань у цій сфері.

\section{1. Історія виникнення та загальна характеристика прав людини першого покоління}

У юридичній літературі традиційно використовують класифікацію прав людини за поколіннями, запропоновану наприкінці 70-х років XX ст. чеським ученим Карелом Васаком. Він прагнув пов'язати три покоління прав людини з трьома гаслами Французької буржуазної революції - свободою, рівністю й братерством. Згодом акценти змістилися у бік суто хронологічного критерію класифікації - часу визнання та забезпечення відповідних категорій прав людини. За такого підходу виділення різних поколінь прав людини набуло переважно історичного значення, а кількість таких поколінь із часом збільшується [6, с. 4]. Дійсно, нові наукові відкриття стали поштовхом до зародження четвертого покоління прав людини, до переліку яких відносять права на зміну статі, трансплантацію органів, штучне запліднення, евтаназію, на доступ до Інтернету, незалежне від державного втручання життя за релігійними та моральними поглядами [2, с. 49].

Першим поколінням прав людини традиційно визнаються особисті (громадянські) та політичні права, поява яких зумовлена процесом виникнення буржуазних революцій у Європі та боротьбою за незалежність у Сполучених Штатах Америки [3, с. 58]. Першими актами конституціоналізму, що закріпили права людини, стали Петиція про права (1628р., Англія), HabeasCorpusAct (1679 р., США) та Білль про права (1689р., 
Англія). До законодавчих актів, у яких були закріплені права першого покоління, також належать американські декларації, серед яких - Декларація прав Вірджинії (1776 р.), Декларація незалежності Сполучених Штатів Америки (1776 р.), Конституція Сполучених Штатів Америки (1787р.), Білль про права (1791 р.), а також французька Декларація прав людини і громадянина (1789 p). Деякі науковці відносять до першого покоління прав людини і Велику хартію вольностей (1215р.) та Литовські статути (1529, 1566 та 1588 рр.). Останні, зокрема, стали юридичними пам'ятками литовського, білоруського та українського народів. У них було проголошено ідеї рівності вільних людей перед законом, особистої недоторканності, юридичного захисту прав вільної особи, особистої відповідальності перед законом. Однак середньовічне законодавство будувалося відповідно до феодально-ієрархічної, станової структури суспільства, коли юридична рівність громадян фактично була відсутня. А тому природно, що відлік першого покоління прав людини варто вести 3 періоду встановлення юридичної рівності всіх людей, коли зруйнувалися станові рамки середньовічного суспільства. На цей період припадає утвердження і розвиток буржуазного суспільства 3 його законодавчими актами. Лише тоді рівноправність людей почала втілюватися у реальну дійсність, набувши конституційного та іншого законодавчого оформлення [4, с. 162-163].

Зазначається, що відповідно до вищезазначених законодавчих актів, до прав людини першого покоління відносять право на життя, свободу та безпеку особи, право громадянина на свободу думки, совісті та релігії, право на участь у здійсненні державних справ, на рівність перед законом, право на гласний розгляд справи незалежним і неупередженим судом, право на свободу слова, друку.

Уважається, що перелічені права першого покоління $\epsilon$ невідчужуваними від людини та виражають незалежність особистості від державної влади. Певна річ, держава зобов'язана утримуватися від утручання у такі права людини шляхом їх надмірного обмеження чи взагалі порушення. Ці права $€$ непорушними і не можуть бути скасовані.

При цьому держава хоча і зобов'язана не втручатися у ці права, проте все ж пов'язана з ними, оскільки, відповідно до конституційних приписів, права і свободи людини та їх гарантії визначають зміст діяльності держави, a утвердження $\mathrm{i}$ 
забезпечення прав і свобод є головним обов'язком держави. За допомогою окремих механізмів права держава забезпечує кожній особі рівні можливості в користуванні суб'єктивними правами.

Зрештою, права людини першого покоління - це права, які захищають свободу людини від необгрунтованого втручання держави. Водночас свобода людини обмежується правовими рамками, які встановлює держава 3 метою регулювання меж реалізації прав людини та виконання функції розв'язання спорів $[3$, c. 58].

Разом із тим права людини першого покоління не обмежуються лише негативними правами, які передбачають обов'язок держави утримуватися від утручання у сфери життєдіяльності людини, врегульовані цими правами. Зміст і взаємозв'язок цих прав удало відображає класифікація, запропонована німецьким юристом і державознавцем Георгом Еллінеком, який виділяв три статуси особи: statusnegativus, statuspositivus, statusactivus, які визначають становище людини в державі і суспільстві залежно від того, як держава забезпечує реалізацію та захист цих прав. Так, statusnegatives формують саме негативні права, якими передбачається недоторканність у сфері індивідуальної свободи, втручатися в яку не можуть ні приватні особи, ні органи державної влади. Негативні права вимагають від держави i приватних осіб утримуватися від дій, що перешкоджають людині реалізовувати свої права і свободи.

Statusnegatives як вимога права на свободу, своєю чергою, породжує і намагання її захисту з боку держави, що, власне, i зумовлює та виправдовує існування держави. У результаті утворюється statuspositives, який включає право на судовий та адміністративний захист у разі порушення statusnegatives із боку приватних осіб або держави. Такий статус передбачає активні (позитивні) дії 3 боку держави в особі іiі органів та їхніх посадових осіб.

Hарешті, statusactivus формує активного громадянина, який домагається права на участь у здійсненні державної влади шляхом участі у формуванні державних органів, у прийнятті державних рішень, у здійсненні публічно-владних повноважень та можливості впливати на владу. Цей статус проявляється через реалізацію людиною таких прав, як право обирати і бути обраним, право на участь у референдумі, право на доступ до державної служби, право на петиції [6, с. 4-5]. 
Права людини в Україні та у зарубіжних країнах: традиції та новації

Безумовно, правам людини першого покоління притаманний дозаконодавчий i позазаконодавчий характер. Ці права $\epsilon$ природними, вони не створюються державою, а лише офіційно нею визнаються, конкретизуються й захищаються [6, с. 4].

Так, право на життя, на повагу до гідності людини, на свободу й особисту недоторканність закріплені в Конституції України як найвищі соціальні цінності, що належать людині. Вони $\epsilon$ первинними та займають центральне місце в Основному Законі України, у державі та суспільстві. Зазначені права обов'язково повинні бути закріплені нормативно, оскільки лише за наявності закріплення цих прав у відповідних правових нормах можна говорити про юридичну підставу встановлення кореспондуючого обов'язку не порушувати ці права. Інакше, якщо такі права визнаватимуть тільки як природні, без їх подальшої юридичної об'єктивації, вони будуть лише черговими декларативними правами, які внаслідок відсутності гарантій їх реалізації та охорони не зможуть бути повною мірою забезпечені силою державного примусу [3, с. 58-59].

\section{2. Становлення і розвиток права на таємницю листування, телефонних розмов, телеграфної та іншої кореспонденції як права першого покоління}

Безперечно, визнання державою прав людини шляхом закріплення їх у національних конституціях та інших законодавчих актах розглядається лише як перший крок до їх утвердження і реалізації. Обсяг прав людини, закріплений у міжнародних документах про права людини, виконує роль взірця, до якого повинні прагнути всі народи й держави. Одним із таких документів $є$ Загальна декларація прав людини 1948 р., яку вважають підсумковим документом, що об’єднав права людини різних поколінь [7, с. 234-235].

Перше покоління громадянських і політичних прав гарантується статтями 2-21 цієї Декларації, а об’єднує їх ідея свободи індивіда, одного чи разом 3 іншими, від зловживань державної влади. Відповідно до статті 12 зазначеного документа, ніхто не може зазнавати безпідставного втручання у його особисте i сімейне життя, безпідставного посягання на недоторканність його житла, таємницю його кореспонденції або на його честь і репутацію. 
Права людини в Україні та у зарубіжних країнах: традиції та новації

Згодом права людини першого покоління отримали належне закріплення в Міжнародному пакті про громадянські та політичні права 1966 р., згідно зі статтею 17 якого ніхто не повинен зазнавати свавільного чи незаконного втручання в його особисте і сімейне життя, свавільних чи незаконних посягань на недоторканність його житла або таємницю його кореспонденції чи незаконних посягань на його честь і репутацію.

До того ж стаття 8 Конвенції про захист прав людини i основоположних свобод 1950 р. гарантує, що кожен має право на повагу до свого приватного і сімейного життя, до свого житла і кореспонденції.

Тому очевидно, що серед інших основних прав людини першого покоління виділяють право на недоторканність особистого (приватного) і сімейного життя людини, похідним від якого $€$ право на таємницю кореспонденції.

Будучи одним з основоположних та невід'ємних прав людини, це право гарантує її свободу й особисту недоторканність, а його забезпечення набуває особливого значення [8, с. 102].

Закріплене в статті 31 Конституції України право на таємницю листування, телефонних розмов, телеграфної та іншої кореспонденції дійсно є одним з основоположних прав людини. Разом із тим варто зазначити, що більшу частину історії становлення цього права займає період формування його основного складника - права на таємницю кореспонденції, яке протягом тривалого часу існувало у формі неписаного права.

Звичайно, дотримання таємниці кореспонденції визнавалося обов'язковим у різних країнах світу ще з давніх часів. Наприклад, у Стародавньому Римі приватні листи було заборонено розкривати навіть за умов, що ознайомлення з ними під час судового процесу могло б принести користь правосуддю. Тобто збереження змісту поштових повідомлень у таємниці мало перевагу перед іншими інтересами античного суспільства. Не менш яскравим прикладом збереження таємниці кореспонденції $\epsilon$ середньовічне Перу, де в період існування цивілізації інків працівників пошти зобов'язували неухильно дотримуватися правил збереження таємниці повідомлень, які через них пересилалися. Із наведених прикладів випливає, що недоторканність таємниці кореспонденції займала вагоме місце серед загальнолюдських цінностей різних народів вже 3 античних часів [9, с. 125]. 
Права людини в Україні та у зарубіжних країнах: традиції та новації

Окрім того, зазначається, що пошта в Давньому Римі виникла і працювала як мережа приватних підприємств,які створювалися представниками підприємницького стану «вершників» (іншими словами, «еквітів» - верстви суспільства, яка в III ст. до н. е. спеціалізувалася переважно на грошових та торговельних операціях). Така пошта працювала на довірі клієнтів і повинна була цю довіру підтримувати. Із цього можна сформувати перший фактор, який вплинув на формування таємниці кореспонденції та обов'язку щодо її збереження - комерційний. Він полягав у тому, що дотримання таємниці листування позначалося на формуванні ділової репутації еквітів у цій сфері, а отже, сприяло залученню нових клієнтів, утриманню користувачів їх послугами i, відповідно, отриманню більшого прибутку [9, с. 126].

Однак у наукових джерелах описується поява у XVII ст. такого негативного явища, як перлюстрація, - таємне розпечатування та перегляд певними органами приватних листів. Ї̈̈ поширення у європейських державах упродовж XVII-XIX ст. спрямувало розвиток права на таємницю кореспонденції у двох напрямах: перший - офіційний, за якого правителі тих часів відкрито проголошували (а згодом i нормативно закріплювали) непорушність таємниці листування, а другий - фактичний, за якого таємно від широкого загалу це правило порушувалося за наказом тих самих правителів, для чого були створені так звані «чорні кабінети» (органи, що займалися перлюстрацією та дешифруванням кореспонденції, і приміщення, які слугували для цих цілей, зазвичай таємні кімнати у поштових відділеннях).

Зокрема, у Франції починаючи 31628 р. у запроваджених кардиналом Ришельє «чорних кабінетах» спеціальні чиновники читали чужі листи, беручи на замітку все, що могло становити інтерес для короля та кардинала. Проте така діяльність трималася урядом у таємниці, щоб не підірвати довіру до офіційної пошти. Зв'язок дотримання таємниці листування (принаймні нерозголошення фактів іiі порушення 3 боку держави) 3 питанням довіри підтверджується зверненнями («наказами») французьких дворян до уряду Франції у 1789 р. Так, французький історик та політичний діяч XIX ст. Алексіс де Токвіль відзначив: «Особливо усі накази одностайно наполягають на необхідності суворо додержуватися таємниці листування з тим, щоб листи не могли слугувати документом у 
Права людини в Україні та у зарубіжних країнах: традиції та новації

суді або засобом обвинувачення. Розкриття листів прямо називається огидним шпигунством, оскільки воно містить у собі порушення суспільної довіри». Однак у даному разі йшлося про довіру не стільки до пошти, скільки до уряду та держави загалом. Своєю чергою, ураховуючи згадувані «накази», дворянство мало й інші інтереси в тому, щоб захистити власну кореспонденцію від чужих утручань. Імовірно, вони могли полягати у тому, щоб уникнути відповідальності за скоєні злочини або запобігти обвинуваченню в державній зраді через сумнівні та невдалі висловлювання. Окрім того, логічним виглядає і прагнення дворян до визнання та підкреслення їх особливого статусу порівняно 3 рештою населення Франції, набуття певних привілеїв тощо.

Із викладеного яскраво простежується описана вище подвійність, яка мала своїм проявом неоднакове ставлення держави до питання таємниці листування. 3 одного боку, за державною вказівкою приватні листи таємно розкривалися i прочитувалися з метою отримання повної інформації про події та настрої у країні. 3 іншого боку, правляча верхівка держави розуміла, що така діяльність не повинна розголошуватися 3 огляду на загальне призначення інституту таємниці листування та іï значення для населення, а тому необхідним кроком було запевнення підданих у тому, що їхні права та інтереси охороняються державою та жодним чином не порушуються. Причому причини обох підходів певною мірою збігалися: це державні інтереси з попередження зневіри населення в державі та заколотів, а також залучення на бік короля певних впливових та заможних осіб.

Подвійне відношення правителів до таємниці листування було характерним і для Російської імперії. Так, у XVIII ст. Катерина II поширила секретними указами «чорні кабінети» по всій російській пошті, наказавши таємно розкривати кореспонденцію на поштамті та особисто їй доставляти. Водночас імператриця публічно поширювала уявлення про дворянську честь і право на особисте життя та вперше за історію існування Російської імперії проголосила таємницю поштової кореспонденції. У такий спосіб імператриця прагнула, з одного боку, заохотити дворянство шляхом публічного визнання особливостей їхнього правового і соціального статусу і надання їм відповідних гарантій та привілеїв, з іншого - простежити за 
тим, щоб у країні не відбувалися будь-які негативні події, серед яких - змови дворян, їхні спроби вчинити переворот та скинути правителя з престолу, та попередити їх шляхом оперативного регулювання [9, с. 127].

Викладені обставини свідчать, з одного боку, про те, що здебільшого формування таємниці листування зумовлювалося необхідністю забезпечення державних інтересів та збереження державних таємниць, захисту репутації та інтересів заможних громадян і панівних верств населення. Це слугувало ще одним та більшою мірою основним чинником, який вплинув на утвердження права на таємницю кореспонденції [9, с. 126-127]. Водночас із розглянутих прикладів можемо сформулювати інший фактор - забезпечення інтересів держави. Проголошення таємниці листування було необхідним у тому числі для:

- формування та зміцнення у свідомості населення довіри до пошти. Подібні обставини сприяли отриманню державою необхідних відомостей, якими громадяни продовжували таємно ділитися один з одним;

- заспокоєння дворян та решти населення тим, що держава захищає їхні інтереси з приводу невтручання інших осіб у їхнє особисте життя, справи, документи, визнає особливий соціальний статус дворян тощо. Це, своєю чергою, слугувало однією з умов попередження зневіри в державі та пошті, а отже, давало змогу зменшити пригніченість серед населення та не допустити тим самим повстання людей проти влади, перевороти, принаймні з цих причин [9, с. 128].

Згодом у 1826 р. в Російській імперії за ініціативи імператора Миколи I було прийнято рішення про видання «Зведення законів Російської імперії». Уважається, що основним джерелом права на приватне життя, на конфіденційну інформацію, листування та телеграфну розсилку був Том 15 цього Зведення [10, с. 243].

Цікавим фактом було поширення на західноукраїнських землях, які в другій половині XVIII ст. потрапили під владу Австрійської монархії, Кримінального кодексу Австрії, який у 1852 р. був викладений у новій редакції. Розділ 37 зазначеного нормативного акту містив положення про порушення приватної таємниці. Так, статтею 253 було передбачено відповідальність за незаконні відкриття чужого листа, телеграфного чи телефонного повідомлення, приєднання до каналу зв'язку, що служить для 
передачі повідомлень, а також розголошення набутої у такий спосіб інформації [10, с. 244].

Забезпечення права на таємницю кореспонденції в Україні розпочалося ще на початку XX ст. Конституція Української Народної Республіки на конституційному рівні закріпила право людини на таємницю кореспонденції шляхом «установлення листової тайни» у статті 16. Окрім того, передбачалося, що «органам державної влади не вільно відкривати листи без судового наказу не інакше, як у випадках, законом означених». Із приходом до влади більшовиків ця Конституція втратила чинність. При цьому з метою централізації діяльності пошти, а також у цілях боротьби 3 бойкотом із боку телеграфних i поштових службовців колишнього режиму 16 квітня 1918 р. був виданий «Декрет про організацію управління поштовотелеграфною справою», який забороняв усім радянським органам влади втручатися в діяльність пошти.

Зазначається, що заборона втручання в таємницю кореспонденції діяла недовго. У жовтні 1918 р. Наркомпоштель видав Циркуляр, яким підтвердив уже безумовне право органів Всеросійської надзвичайної комісії 3 боротьби 3 контрреволюцією і саботажем (далі - ВЧК) затримувати кореспонденцію. А у грудні 1918 р. було затверджено положення «Про військову цензуру», яким уводився перегляд міжнародної та внутрішньої поштово-телеграфної кореспонденції і контроль над переговорами по міжміському телефону.

Із 1922 р. перлюстрацію кореспонденції став здійснювати Відділ політконтроля Секретно-оперативного управління Державного політичного управління (ГПУ), а також його місцеві підвідділи, відділення та пункти. Звичайно, у період із 1922 по 1937 р. перлюстрація кореспонденції на конституційному рівні не заборонялася, оскільки Конституції УРСР в редакціях 1919 та 1929 pр. не містили положень, які закріплювали право на таємницю кореспонденції. Лише Конституція УРСР в редакції 1937 р. закріпила право людини на таємницю кореспонденції [11, с. 236].

Пізніше у зв'язку з ратифікацією у 1977 р. Міжнародного пакту про громадянські та політичні права була прийнята нова Конституція УРСР. Вона стала першою й єдиною за весь радянсько-український період Конституцією, що вміщувала в окремому розділі стандартний для розвинених європейських країн комплекс громадських, політичних, економічних, 
Права людини в Україні та у зарубіжних країнах: традиції та новації

соціальних i культурних прав. Зокрема, статтями 52-54 громадянам були гарантовані недоторканність особи, житла, а також охорона законом особистого життя, таємниці листування, телефонних розмов і телеграфних повідомлень. У статті 55 цієї Конституції було наголошено, що повага до особистості, охорона прав і свобод громадян - це обов'язок усіх державних органів, громадських організацій і посадових осіб [10, с. 245].

Згодом положення чинної в Україні Конституції 1996 p. значно розширили норми щодо забезпечення права особи на таємницю листування, телефонних розмов, телеграфної та іншої кореспонденції порівняно 3 аналогічними положеннями Конституцій УРСР 1937 та 1978 рр.

Безумовно, завдяки науковим дослідженням українських учених у період «сталого» (1996-2004 рр.) та «міжмайданного» (20042014 рр.) конституціоналізму законодавцями також було вдосконалено юридичний механізм реалізації гарантій таємниці кореспонденції через притягнення винних у порушенні цієї таємниці осіб до кримінальної відповідальності. Також удосконалено юридичний механізм «законного обмеження» таємниці кореспонденції в процесі кримінального провадження державними правоохоронними органами. Окрім того, не менш важливим кроком українських законотворців стало закріплення права на таємницю кореспонденції у цивільному законодавстві як одного з видів особистих немайнових прав людини [12, с. 64-65].

\section{3. Сучасний стан та проблеми забезпечення права на таємницю листування, телефонних розмов, телеграфної та іншої кореспонденції}

Як уже зазначалося, права першого покоління, тобто громадянські та політичні права, були проголошені першими буржуазними революціями у Сполучених Штатах Америки та Європі і закріплені відповідними деклараціями, але у цих документах ще не йшлося про права i свободи людини в інформаційній сфері.

Відповідно до чинного законодавства, до громадянських (особистих) прав і свобод людини відносять: право на життя, право на повагу честі і гідності людини, право на свободу й особисту недоторканність, недоторканність приватного життя, житла, свободу пересування і вибору місця проживання, свободу вираження поглядів, свободу інформації, таємницю листування 
Права людини в Україні та у зарубіжних країнах: традиції та новації

тощо. Більшість із перерахованих прав має своїм основним об'єктом інформацію [13, с. 119].

Зрозуміло, що Конституція України закріплює основний зміст прав і свобод в інформаційній сфері, але їх конкретизація відображається й у низці інших нормативно-правових актів $[13$, с. 118$]$.

Чинний Цивільний кодекс України містить цілий комплекс можливостей особи інформаційного характеру, які певною мірою можна називати інформаційними правами. Будучи відносно новими, переважна їх частина виокремилася з «класичних» прав (права на життя, свободу, повагу до честі та гідності, особисту недоторканність, працю, освіту тощо) під впливом тенденцій становлення інформаційного суспільства. Деякими науковцями висловлюється думка щодо неоднозначності приналежності права у інформаційній сфері до якогось конкретного покоління прав людини.

До того ж науковці у сфері цивільного права зазначають, що безпосередньо закріплені «інформаційні права першого покоління» визначають невідчужувані так звані «негативні свободи», які виражаються в недоторканності особи та можуть бути обмежені виключно на законних підставах в інтересах національної безпеки, суспільного порядку і добробуту, прав людини. До таких прав відносять і право на таємницю кореспонденції, закріплене у статті 306 Цивільного кодексу України [14, с. 106].

Конституційними нормами України гарантується, що кожен, хто знаходиться на території України або під ії юрисдикцією, має конституційне право на таємницю листування, телефонних розмов, телеграфної та іншої кореспонденції. Проте для України і надалі залишається невирішеною проблема забезпечення цього права, особливо в сучасному інформаційному середовищі.

Варто зазначити, що дія Закону України «Про основні засади забезпечення кібербезпеки України» не поширюється на соціальні мережі, приватні електронні інформаційні ресурси в мережі Інтернет, якщо такі інформаційні ресурси не містять інформацію, необхідність захисту якої встановлена законом, відносини та послуги, пов'язані з функціонуванням таких мереж та ресурсів. А тому кореспонденція приватних осіб, яка поширюється в такому кіберпросторі, фактично залишається поза захистом. 
Права людини в Україні та у зарубіжних країнах: традиції та новації

Суперечливість дії норм вищевказаного закону полягає й у тому, що об'єктами кібербезпеки є конституційні права і свободи людини і громадянина, в тому числі конституційне право на таємницю листування, телефонних розмов, телеграфної та іншої кореспонденції. Очевидно, що кожна особа, яка фізично перебуває на території України, спілкуючись в кіберпросторі через передачу або прийом її кореспонденції, у разі виникнення кіберзагроз потребує захисту 3 боку Української держави виходячи 3 наданих їй статтею 31 вітчизняної Конституції гарантій. У результаті виникає проблема реального, а не декларативного, забезпечення конституційного права особи на таємницю листування, телефонних розмов, телеграфної та іншої кореспонденції, притому, що, власне, на людину з боку держави не покладається жодного обов'язку вжити всіх можливих заходів щодо забезпечення інформаційної безпеки кореспонденції, що передається [15, с. 26-27].

Безумовно, сьогодні в правовому регулюванні механізму захисту права на таємницю листування, телефонних розмов, телеграфної та іншої кореспонденції дійсно вбачається багато прогалин. На практиці трапляються непоодинокі випадки відхилення від норм забезпечення права на таємницю кореспонденції, а отже, це право систематично зазнає втручань чи обмежень [8, с. 102].

Так, наприклад, аналіз норм чинних нормативно-правових актів у сфері контролю над дотриманням операторами поштового зв'язку законодавства, зокрема щодо забезпечення таємниці листування, телефонних розмов, телеграфної та іншої кореспонденції, показує, що повноваження державних органів у цій сфері $\epsilon$ суто декларативними, адже конкретний механізм їх реалізації законодавчо не визначений.

Відповідно до Закону України «Про телекомунікації», органом державного регулювання у сфері телекомунікацій є Національна комісія, що здійснює державне регулювання у сфері зв'язку та інформатизації, яка здійснює державний нагляд за ринком телекомунікацій шляхом проведення планових і позапланових перевірок, інших заходів, визначених законодавством, спрямованих на запобігання порушенням законодавства суб'єктами ринку телекомунікацій, виявлення й усунення таких. Інформація про проведені перевірки та їхні результати оприлюднюється. Проте ця інформація не містить конкретних відомостей щодо порушень саме у сфері забезпечення права на 
таємницю листування, телефонних розмов, телеграфної та іншої кореспонденції. Таким чином, ситуація у сфері контролю над дотриманням прав людини у сфері телекомунікацій виглядає дещо кращою, ніж у сфері кореспонденції в кіберпросторі, проте відсутність офіційної інформації про наявні правопорушення ще не вказує на відсутність таких порушень [16, с. 66].

Окремою проблемою постає надання інформації щодо кореспонденції особи на вимогу правоохоронних органів чи суду. Одним із обов'язків оператора телекомунікацій має бути вжиття відповідно до законодавства заходів із забезпечення таємниці телефонних розмов чи іншої інформації, що передається телекомунікаційними мережами, конфіденційності інформації про споживача та послуги, які він отримав чи замовляв. Але навіть закріплення операторами такого положення в договорах не убезпечує від можливості неправомірного втручання в право користувачів на таємницю телефонних розмов, телеграфної та іншої кореспонденції.

У національній судовій практиці відомі випадки, коли оператор мобільного зв'язку зобов'язаний надати інформацію, яка порушує таємницю кореспонденції особи, наприклад записи та роздруківки телефонних розмов між абонентами, на виконання припису суду. Суд, своєю чергою, постановляє ухвалу про забезпечення доказів шляхом витребування інформації в оператора мобільного зв'язку відповідно до норм Цивільного процесуального кодексу України.

При цьому, надаючи інформацію на запит суду, оператор може порушити норми Конституції України, а відмовляючись від надання цієї інформації, - положення іншого законодавства. Оскільки Конституція України має вищу юридичну силу, то здається логічним у такому разі передусім дотримуватися норм саме Конституції. Але на практиці все зазвичай відбувається навпаки.

До того ж існує проблема відсутності дієвого судового контролю над здійсненням утручання в право особи на таємницю листування, телефонних розмов, телеграфної та іншої кореспонденції. Адже сьогодні функція слідчого судді зводиться лише до розгляду клопотання про надання дозволу на втручання в це право та прийнятті рішення про його задоволення чи відмову у задоволенні. Однак утручання правоохоронних органів у права окремих осіб повинно перебувати під ефективним контролем, який, звичайно, має забезпечуватися судовою системою, у всякому разі як останньою інстанцією [17, с. 122-123]. 
Варто також зауважити, що для деяких суб'єктів право на таємницю листування, телефонних розмов, телеграфної та іншої кореспонденції зазнає певних трансформацій, які пов'язані 3 їхнім статусом. Якщо для одних, як, наприклад, для осіб, засуджених до позбавлення волі, прямо встановлено обмеження цього права, то інші, як-то представники влади, користуються вищим імунітетом від незаконного чи свавільного втручання в таємницю їхньої кореспонденції [8, с. 102].

Окрім того, науковці визначають й інші причини та передумови появи проблем у сфері гарантування недоторканності права на таємницю листування, телефонних розмов, телеграфної та іншої кореспонденції. Серед них відсутність легальних визначень понять «листування», «телефонні розмови», «телеграфна кореспонденція», які у сукупності утворюють загальне поняття «кореспонденція»; відсутність дієвого прокурорського нагляду і судового контролю над накладенням арешту на кореспонденцію та зняттям інформації з транспортних телекомунікаційних та електронних інформаційних систем; відсутність у національному законодавстві норм правового регулювання електронної кореспонденції в мережі Інтернет [16, с. 66-67]; недосконалість інституту юридичної відповідальності держави в особі їі правоохоронних органів за необгрунтоване та незаконне втручання в право на таємницю кореспонденції, а також часті зміни в системі органів, уповноважених на здійснення правомірного втручання у це право, та недоліки нормативноправових актів, що визначають їхні повноваження, їх невідповідність Конституції України та нормам міжнародного права. Подібного роду прогалини в законодавстві та на практиці не можуть не позначитися на умовах життя людей. У такому разі ніхто не може бути застрахованим від порушень таємниці кореспонденції [18, с. 92-93].

\section{Висновки}

Таким чином, гарантоване Конституцією України право на таємницю листування, телефонних розмов, телеграфної та іншої кореспонденції, яке науковці відносять до прав першого покоління прав людини, пройшло тривалий шлях становлення та розвитку. Сформувавшись ще в період античності у формі неписаного права як похідне від права на повагу i недоторканність приватного і сімейного життя, сьогодні це 
право реалізується в абсолютно нових умовах. Розвиток методів обміну і поширення інформації, зумовлений безпрецедентними темпами науково-технічного прогресу в галузі телекомунікаційних технологій, призвів до виникнення практично необмежених можливостей інформаційного впливу на всі сфери життя сучасної людини [14, с. 104]. При цьому ефективний механізм захисту зазначеного права фактично відсутній. На практиці часто виникають ситуації, коли задеклароване на конституційному рівні право на таємницю кореспонденції порушується як із боку інших приватних осіб, так і з боку держави [16, с. 65].

Такі проблеми є серйозною перепоною на шляху України як дійсно правової держави, в якій не лише проголошений, а й реалізується принцип пріоритету прав людини, а тому вони потребують невідкладного вирішення [16, с. 69]. Зокрема, пропонується внести зміни до чинного національного законодавства у сфері таємниці кореспонденції, у тому числі шляхом прийняття та реалізації спеціального закону про гарантії прав людини на таємницю кореспонденції, який обов'язково враховуватиме міжнародні стандарти у сфері таємниці кореспонденції. У такому законі рекомендується закріпити визначення понять «листування», «телефонні розмови», «телеграфна кореспонденція», які у сукупності утворюють загальне поняття «кореспонденція». До того ж потрібно виробити конкретні умови забезпечення таємниці кореспонденції під час експлуатації систем зв'язку загального користування. Сьогодні гостро відчувається потреба у створенні дієвих механізмів судового контролю забезпечення таємниці листування, телефонних розмов, телеграфної та іншої кореспонденції. Також необхідно створити умови для набуття кожною особою засобів захисту інформації, яка становить таємницю її кореспонденції, для використання в каналах зв'язку загального користування та забезпечити контроль із боку уповноважених державних органів за якістю таких засобів. Зрештою, у сучасних умовах розвитку інформаційних технологій, що спричинюють, з одного боку, появу й удосконалення засобів електронної кореспонденції, 3 іншого - створюють ширші можливості для спостереження за кореспонденцією особи, особливого захисту потребує право на таємницю електронної кореспонденції, захист якого можливо забезпечити шляхом урегулювання цього питання на законодавчому рівні в 
Права людини в Україні та у зарубіжних країнах: традиції та новації

найкоротші строки, оскільки Закон України «Про електронні комунікацій» від 16 грудня 2020 р. все ще не набрав чинності.

Зазначені заходи в сукупності мають дати позитивний результат у вигляді створення ефективної системи забезпечення одного з основоположних прав людини першого покоління прав людини - права на таємницю листування, телефонних розмов, телеграфної та іншої кореспонденції.

\section{Список використаних джерел:}

1. Левченко А.В. Забезпечення права на таємницю кореспонденції в умовах надзвичайного стану: закордонний досвід для України. KELM (Knowledge, Education, Law, Management). 2020. № 4(32). С. 189-194.

2. Данільцева В.Г. Покоління прав людини. Юридична наука: сучасний стан та перспективи розвитку : матеріали міжвузівської науково-практичної конференції, м. Київ, Міністерство внутрішніх справ України, Національна академія внутрішніх справ, 30 листопада 2017 р. Київ, 2017. С. 48-49.

3. Шебаніц Д.М. Сучасна проблематика теорії «поколінь прав людини» в умовах європейської міждержавної інтеграції. Науковий вісник Ужгородського національного університету. Серія «Право». 2015. Вип. 31. Т. 1. С. 57-61.

4. Ковшик А.О. Покоління прав людини: поняття та загальна характеристика. URL: http://dspace.pnpu.edu.ua/ bitstream/123456789/3694/1/Kovschik.pdf___дата_ звернення: 12.04.2021).

5. Калюжний К.Р. Сутність інформаційних прав людини в науці інформаційного права. Юридичний вісник. 2012. № 4(25). C. 55-58.

6. Дашковська О.Р. Покоління прав людини як соціальна форма опосередкування свободи. Науковий вісник Міжнародного гуманітарного університету. Серія «Юриспруденція». 2016. № 22. C. $4-7$.

7. Слюсар К. Закріплення поколінь прав людини в міжнародних документах. Підприємництво, господарство і право. 2017. № 12. С. 234-238.

8. Міхневич Л.В. Конституційне право на таємницю листування, телефонних розмов, телеграфної та іншої кореспонденції окремих категорій осіб. Часопис Київського університету права. 2020. № 4. С. 102-106. 
Права людини в Україні та у зарубіжних країнах: традиції та новації

9. Токар Н.В. Історія розвитку права на таємницю кореспонденції та причини його виникнення. Науковий вісник Міжнародного гуманітарного університету. Серія «Юриспруденція». 2015. № 18. Т. 1. С. 125-129.

10. Кондратенко Н.М. Особливості розвитку правовідносин у сфері захисту персональних даних: історико-джерелознавчий аспект. Форум права. 2013. № 2. С. 241-247.

11. Черевко М.О. Конституційне право людини на таємницю листування та телефонних розмов в Україні: ретроспективний аналіз. Матеріали VIII наук. читань, присвяч. пам'яті акад. B.B. Копєйчикова, 22 листопада 2018 р. Київ, 2018. С. 236-238.

12. Черевко М.О. Доктринальні дослідження конституційного права людини на таємницю листування, телефонних розмов, телеграфної та іншої кореспонденції та його забезпечення в Україні. Конституційно-правові академічні студії. 2019. Вип. 1. C. 63-69.

13. Діордіца I. Класифікація інформаційних прав і свобод людини і громадянина. Підприємництво, господарство і право. 2016. № 7. С. 116-122.

14. Тихомиров 0.0. Інформаційні права людини як цивільноправова категорія. Юридичний вісник. 2015. № 1(34). С. 104-109.

15. Даценко М.С. Конституційно-правові засади інформаційної безпеки у парадигмі «війни нового покоління». URL: http://dspace.onua.edu.ua/bitstream/handle/11300/ 12940/Nove\%20pokolinnya.pdf?sequence=1\&isAllowed=y___ (дата звернення: 16.04.2021).

16. Говорун В.В. Організаційно-правові гарантії непорушності (недоторканності) права громадян на таємницю листування, телефонних розмов, телеграфної та іншої кореспонденції. Правові новели. 2018. № 6. С. 65-69.

17. Левченко А.В. До проблеми захисту конституційного права на таємницю листування, телефонних розмов, телеграфної та іншої кореспонденції. Основні права людини: розуміння та виклики : матеріали Міжнародної науково-практичної конференції, м. Київ, Київський національний університет імені Тараса Шевченка, 10 грудня 2019 р. Київ, 2019. С. 120-123.

18. Левченко А.В. Гарантії забезпечення конституційного права на таємницю листування, телефонних розмов, телеграфної та іншої кореспонденції. Держава і право. 2019. Вип. 86. С. 86-95. 